\title{
Determinants of Paddy Fields Conversion in Java Island, Indonesia
}

\author{
Edmon Daris $^{a^{*}}$, Iwan Aminudin ${ }^{\mathrm{b}}$, and Adhitya Feriansyah ${ }^{\mathrm{c}}$ \\ ${ }^{a, b, c}$ Department of Agribusiness, Faculty Science and Technology \\ Syarif Hidayatullah State Islamic University Jakarta \\ Tangerang Selatan, Indonesia \\ *Email: edmondaris@uinjkt.ac.id
}

\begin{abstract}
Rice is a main staple food of Indonesia. Availability of rice is not separated from Java island as the largest rice supplier in Indonesia. Almost 52\% of Indonesia's rice production is produced on the Java island. However, production growth is only $0,7 \%$ given the increasing number of people. One of the causes is the increasing land conversion over the past 7 years. This study aims to 1) to identify how much land conversion in Java island from 1994 to 2014,2$)$ to analyze what factors affect the conversion of paddy fields in Java island, and 3) to calculate the impact of paddy field conversion on paddy production and economic value of farmer job for 21 years in Java island. The results indicate that during the period of 1994 to 2014, Java island experienced a conversion of rice fields of 1.2 million hectares or about 60 thousand hectares per year. Productivity of paddy rice, economic growth (GRDP), length of asphalt road, and population growth have significant effect on the conversion of paddy fields in Java island. For 21 years, Java island has lost the opportunity to produce rice by 6.7 million tons with a value of Rp 24,282 trillion rupiah.
\end{abstract}

Keywords: Land conversion, Rice Field, Rice, Java Island

\section{Introduction}

Rice production in Java Island is the largest among the other islands, reached 36 million tons in 2014. In addition, rice production in Java Island accounts for $52 \%$ of total rice production in Indonesia [1]. This makes Java as the main producer and the largest rice supplier in Indonesia. However, it is unfortunate that the growth of rice production in Java is the smallest, i.e. only $0.7 \%$ during the last 5 years. The small growth of Java's rice production by $0.7 \%$ is alarming, as Java is a supplier of $50 \%$ of the total rice production in Indonesia. One of the causes is the conversion of agricultural land. Every year there are always paddy fields in Java Island, which is converted to non-agricultural land (Table 1).

Table 1. Paddy field in Java Island from 2008 until 2014

\begin{tabular}{|c|c|}
\hline Year & Size (ha) \\
\hline 2008 & 3.270 .221 \\
\hline 2009 & 3.251 .007 \\
\hline 2010 & 3.253 .594 \\
\hline 2011 & 3.251 .694 \\
\hline 2012 & 3.446 .295 \\
\hline 2013 & 3.231 .680 \\
\hline 2014 & 3.248 .394 \\
\hline
\end{tabular}

Table 1 indicates that the area of paddy field in Java Island has decreased since the last 6 years. The largest decline occurred in 2009 amounted to 214,615 ha. Reduced paddy fields will result in reduced number of existing farmers and will threaten the amount of rice production. This is caused by many factors such as increasing population, increasing economic growth, decreasing farmers' productivity, ease of road access, and the development of property business. Therefore, in this study, we identified the factors affecting land conversion and calculated the impact of land conversion on rice production lost for the last 21 years.

\section{Research Method}

This study used secondary data in the form of time series for 15 years (1994-2014) obtained from the Ministry of agriculture, Ministry of public works, and the Central Bureau of Statistics in Indonesia. Data collection was conducted in Jakarta in May 2016. Multiple linear regression method was used to analyze data with the following model:

$\mathrm{Y}=\mathrm{a}_{0}+\mathrm{b}_{1} \mathrm{X}_{1}+\mathrm{b}_{2} \mathrm{X}_{2}+\mathrm{b}_{3} \mathrm{X}_{3}+\mathrm{b}_{4} \mathrm{X}_{4}+\mathrm{b}_{5} \mathrm{X}_{5}+\mathrm{b}_{6} \mathrm{X}_{6}+\mathrm{e}$

Where:

$\mathrm{Y}=$ Agricultural Land Conversion $(\mathrm{Ha})$

$\mathrm{X}_{1}=$ Rice Productivity (quintal/Ha)

$\mathrm{X}_{2}=$ Regional Economic Growth (GRDP) (Trillion)

$\mathrm{X}_{3}=$ Asphalt Road Length $(\mathrm{Km})$

$\mathrm{X}_{4}=$ Percentage of irrigated paddy fields (\%)

$\mathrm{X}_{5}=$ Number of Motorized Vehicles (Thousand units)

$\mathrm{X}_{6}=$ Population (Million people)

$\mathrm{e}=$ standard error

\section{Results And Discussion}

\subsection{Paddy Field Conversion Pattern in Java Island}

Land conversion in Java occurs almost every year, especially in paddy field. This is due to the shifting of land use from agriculture to non-agricultural. The area of paddy field that is converted based on data from Pusdatin Ministry of Agriculture during the period 1994-2014 is indicated in table 2 [2]. 
Table 2. Paddy field conversion in Java Island from 1993 until 2014

\begin{tabular}{|c|c|c|}
\hline Year & Size (ha) & Land conversion (ha) \\
\hline 1994 & 3163772 & 57199 \\
\hline 1995 & 3146746 & 17026 \\
\hline 1996 & 3126842 & 19904 \\
\hline 1997 & 3115704 & 11138 \\
\hline 1998 & 3105593 & 10111 \\
\hline 1999 & 3158527 & 19386 \\
\hline 2000 & 3347685 & 24024 \\
\hline 2001 & 3319023 & 28662 \\
\hline 2002 & 3282745 & 36278 \\
\hline 2003 & 3316172 & 144652 \\
\hline 2004 & 3063147 & 253025 \\
\hline 2005 & 3258616 & 140180 \\
\hline 2006 & 3231281 & 27335 \\
\hline 2007 & 3247502 & 23274 \\
\hline 2008 & 3270221 & 21244 \\
\hline 2009 & 3251007 & 19214 \\
\hline 2010 & 3253594 & 10557 \\
\hline 2011 & 3251694 & 59408 \\
\hline 2012 & 3446295 & 108248 \\
\hline 2013 & 3231680 & 214615 \\
\hline
\end{tabular}

Source: [2]

From the table 2, it is indicated that the total amount of land conversion of paddy fields occurred for 1,265,223 hectares with an average of 60,249.19 hectares per year. As for the area of paddy field conversions that occurs, the magnitude from year to year tends to be unstable due to the opening of paddy fields in certain years. The largest land conversion occurred in 2004 that amounted to 253,025 hectares, while the smallest land conversion occurred in 1998 that amounted to 10,111 hectares.

\subsection{Determinants of paddy field conversion in Java Island}

Based on the calculation by using SPSS 18, the results obtained for multiple linear regression calculations of factors affecting paddy field conversion in Java island are indicated in table 3 .

\begin{tabular}{|c|c|c|c|c|c|}
\hline \multirow{2}{*}{ Model } & \multicolumn{2}{|c|}{ Unstandardized Coeff. } & \multirow{2}{*}{$\begin{array}{c}\begin{array}{c}\text { Standardiz } \\
\text { ed Coeff. }\end{array} \\
\beta\end{array}$} & \multirow{2}{*}{$\begin{array}{c}\mathrm{t}- \\
\text { valu } \\
\mathrm{e}\end{array}$} & \multirow{2}{*}{ Sig. } \\
\hline & B & Std. Error & & & \\
\hline Constant & $\begin{array}{l}1205125,9 \\
91\end{array}$ & $\begin{array}{l}4307484,8 \\
36\end{array}$ & & $\begin{array}{l}0,28 \\
0\end{array}$ & $\begin{array}{l}0,78 \\
4\end{array}$ \\
\hline $\begin{array}{l}\text { Rice } \\
\text { Productivi } \\
\text { ty }\end{array}$ & $-4474,538$ & 17405,533 & -220 & $\begin{array}{l}- \\
2,25 \\
7\end{array}$ & $\begin{array}{l}0,03 \\
8\end{array}$ \\
\hline $\begin{array}{l}\text { Java } \\
\text { PDRB }\end{array}$ & 161,353 & 432,976 & 0,940 & $\begin{array}{l}2,37 \\
3\end{array}$ & $\begin{array}{l}0,01 \\
7\end{array}$ \\
\hline $\begin{array}{l}\text { Asphalt } \\
\text { Road } \\
\text { Length }\end{array}$ & 36,480 & 51,287 & 1,971 & $\begin{array}{l}3,71 \\
1\end{array}$ & $\begin{array}{l}0,04 \\
9\end{array}$ \\
\hline $\begin{array}{l}\text { Percentag } \\
\mathrm{e} \quad \text { of } \\
\text { irrigated } \\
\text { paddy } \\
\text { field }\end{array}$ & $-3760,741$ & 41850,237 & $-0,154$ & $\begin{array}{l}- \\
0,09 \\
0\end{array}$ & $\begin{array}{l}0,93 \\
0\end{array}$ \\
\hline $\begin{array}{l}\text { Number of } \\
\text { vehicles }\end{array}$ & 2,782 & 7,907 & 0,641 & $\begin{array}{l}0,35 \\
2\end{array}$ & $\begin{array}{l}0,73 \\
0\end{array}$ \\
\hline $\begin{array}{l}\text { Total } \\
\text { population }\end{array}$ & 12605,271 & 27339,210 & 2,012 & $\begin{array}{l}3,46 \\
1\end{array}$ & $\begin{array}{l}0,02 \\
7\end{array}$ \\
\hline
\end{tabular}

Source: Processed secondary data
Based on the results in table 3, it is proven that rice productivity variables, Java GDP, long asphalt road, and population significantly affect the conversion of paddy fields in Java Island. The coefficient of rice productivity $\left(\mathrm{X}_{1}\right)$ is $-4474,538$. This means that if rice productivity increases by 1 quintal/Ha per year, the land conversion will decrease by 4474,538 hectares per year, ceteris paribus. This result is in accordance with the study by [3] which states that land conversion takes place from activities with lower land rent to activities with higher land rents. Furthermore, according to [4] there are two important aspects that determine the economic value of land where one of them is the fertility of the land. David Ricardo in [4] suggests Richardian Rent Theory that soil fertility rates can affect the economic value of the land. Therefore, increased in rice productivity will be able to reduce the amount of land conversion that occurs. As greater productivity increases the amount of rice production that will directly add to the farmer's gross income [6], [7].

The coefficient of GDRP $\left(\mathrm{X}_{2}\right)$ is 161,353 . This means that if the GRDP Java island increased by 1 trillion rupiah per year, the land conversion will increase by 161,353 hectares per year ceteris paribus. These results are consistent with studies by [8], [9], and [10] which suggest that agricultural land conversion occurs as a result of land use competition between agriculture and non-agricultural sectors. Competition occurs because of three aspects of land resources, population growth, and economic growth. Economic growth tends to encourage demand for land for non-agricultural activities at a higher rate than the demand for land for agricultural activities, because non-agricultural products are more elastic to income. So the increasing scarcity of land (due to population growth), coupled with the increasing demand for relatively high land for nonagricultural activities (due to economic slump) eventually led to the conversion of agricultural land.

The coefficient of length of asphalt road of Java $\left(\mathrm{X}_{3}\right)$ is 36,480 . This means that if the length of the asphalt road of Java has increased by $1 \mathrm{~km}$ per year, the land conversion will increase by 36.480 hectares per year ceteris paribus. This result is in accordance with the theory expressed by Von Thunen in [4] that the economic surplus of a land is largely determined by the economic location. According to Von Thunen, the cost of transportation from the location of a land to the city (the market) is an important input of production, the closer the location of a land to the city, the higher the accessibility or the lower the transport cost. It is implied that transportation convenience can be one of the causes of the conversion of paddy fields. In addition Saefulhakim in [5] suggests that one of the important factors that can lead to the conversion process of agricultural land to non-farm is accessibility. The changes in transportation facilities and infrastructure that have implications for increased local accessibility will further encourage the development of agricultural land use to nonagricultural. This is in accordance with the regression results in accordance with the theory that the increasing accessibility (asphalt road) will increase the amount of paddy field conversion [6], [7]. 
The coefficient of population $\left(\mathrm{X}_{6}\right)$ is 12605,271 . This means that if the population of Java island increased by 1 million people per year, the land conversion will increase by 12605.227 hectares per year ceteris paribus. This result is consistent with studies by [8], [11] and [7] that agricultural land conversion is essentially due to competition in land use between agriculture and nonagricultural sectors. Competition in the utilization of the land arises due to the existence of economic and social phenomena of limited land resources, population growth, and economic growth. In each region, the area of land available is relatively fixed or limited so that population growth will increase the scarcity of land that can be allocated for agricultural and non-agricultural activities. Meanwhile, economic growth tends to encourage demand for land for non-agricultural activities at a higher rate than the demand for land for agricultural activities because demand for non-agricultural products is more elastic to income. Increased land scarcity (due to population growth), coupled with a relatively high demand for land for non-agricultural activities (due to economic growth) ultimately leads to conversion of agricultural land. Furthermore, simultaneous test results of independent variables by using an F-test indicates that all of the variables simultaneously have effects on paddy field conversion in Java island (F-value of 3,502> F-table of 2,848).

\subsection{Estimated loss of production}

The transfer of paddy field to other uses automatically changes the amount and type of benefits that can be received from the use of the field. Losses due to paddy field conversion are primarily the loss of opportunities of producing agricultural production that is directly proportional to the area of converting land. These types of losses include a decrease in agricultural production and its value, farm income, employment opportunities in farming activities, loss of benefits from converted paddy field investment, changes in environmental quality and other economic activities created from the farming activities. However, in this study, we only analyzed the reduction of production and its value.

The average productivity of paddy field in Java island from 1994 until 201452.747 quintal per hectare per year with average productivity growth of 0.551 percent of paddy per year [2]. The losses arising from the conversion of paddy fields in Java are indicated in table 4.

Table 4. Estimated production loss due to conversion of paddy fields in Java Island

\begin{tabular}{|l|l|l|l|}
\hline Year & $\begin{array}{l}\text { Paddy } \\
\text { productivity } \\
\text { (quintal/ha) }\end{array}$ & $\begin{array}{l}\text { Land } \\
\text { conversion } \\
\text { (ha) }\end{array}$ & $\begin{array}{l}\text { Lost of } \\
\text { production } \\
\text { (quintal) }\end{array}$ \\
\hline 1994 & 50,95 & 57199 & 2914289,05 \\
\hline 1995 & 50,08 & 17026 & 852662,08 \\
\hline 1996 & 50,08 & 19904 & 996792,32 \\
\hline 1997 & 50,51 & 11138 & 562580,38 \\
\hline 1998 & 50,7 & 10111 & 512627,7 \\
\hline 1999 & 47,74 & 19386 & 925487,64 \\
\hline 2000 & 49,13 & 24024 & 1180299,12 \\
\hline 2001 & 49,8 & 28662 & 1427367,6 \\
\hline
\end{tabular}

\begin{tabular}{|l|l|l|l|}
\hline 2002 & 50,39 & 36278 & 1828048,42 \\
\hline 2003 & 50,39 & 144652 & 7289014,28 \\
\hline 2004 & 50,82 & 253025 & 12858730,5 \\
\hline 2005 & 51,66 & 140180 & 7241698,8 \\
\hline 2006 & 51,66 & 27335 & 1412126,1 \\
\hline 2007 & 53,35 & 23274 & 1241667,9 \\
\hline 2008 & 55,6 & 21244 & 1181166,4 \\
\hline 2009 & 57,25 & 19214 & 1100001,5 \\
\hline 2010 & 56,89 & 10557 & 600587,73 \\
\hline 2011 & 55,94 & 59408 & 3323283,52 \\
\hline 2012 & 59,66 & 108258 & 6458672,28 \\
\hline 2013 & 58,3 & 214615 & 12512054,5 \\
\hline 2014 & 56,79 & 19743 & 1121204,97 \\
\hline $\begin{array}{l}\text { Rata } \\
\text { Rata }\end{array}$ & 52,75 & 60249,19 & 3216207,75 \\
\hline Total & & & \\
\hline So Pran & 1265233 & 67540362,79 \\
\hline
\end{tabular}

Source: Processed secondary data (2015)

Table 4 indicates that the average loss of rice production is $3,063,017,394$ quintals per year. In total, assuming if the land is not converted and farmers continue to cultivate rice crops, then the amount of rice production lost in the year from 1994 until 2014 amounted to 6,754,036,279 quintals.

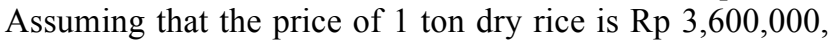
then the loss of the production value will be $6,754,036,279$ ton times $\mathrm{Rp} 3,600,000$ per ton which is equal to $\mathrm{Rp}$ $24,282,130,604,400$ or about Rp 24,282 trillion, while the average lost per year is $321,620,775$ tons times $\mathrm{Rp}$ $3,600,000$ per ton which is equal to Rp. $1,157,834,790,000$ or approximately $\mathrm{Rp} 1,157$ trillion.

\section{Conclusion and Recommendation}

\subsection{Conclusion}

4. During the period of 1994 until 2014 Java Island has experienced a conversion of paddy fields of 1.2 million hectares or about 60 thousand hectares per year.

5. Productivity of paddy fields, regional economic growth, length of asphalt road, and growth of population have significant effects on paddy field conversion in Java island while the percentage of irrigated land and the number of vehicles have no effects at all.

6. For 21 years, Java island has lost the opportunity to produce rice by 6.7 million tons with a value of $\mathrm{Rp}$ 24.282 trillion rupiah

\subsection{Recommendation}

Based on the above conclusions, we suggest as follows:

1. Rice productivity should be improved by creating a new irrigation system and facilitating development in the agricultural sector, especially rice commodities.

2. Economic growth should be directed to the agricultural sector so that land conversion dose not occur. Population growth needs to be suppressed in accordance with government programs on population control efforts. 
Moreover, the control of immigrants from other islands is also needed.

3. Construction of asphalt road should be done properly, such as the construction of non-toll overpasses and it does not take place near rice fields.

\section{References}

[1] Ministry of Agriculture. 2015. Produksi Padi Pada PulauPulau Besar di Indonesia Tahun 2010 - 2015.

[2] Pusdatin. 2015. Luas Lahan Sawah Pulau Jawa Tahun 2008 - 2014. DKI Jakarta : Kementrian Pertanian.

[3] Rustiandi, E. 2001. Alih Fungsi Lahan Dalam Perspektif Lingkungan Perdesaan. Di dalam : Lokakarya Penyusunan Kebijakan dan Strategi Pengelolaan Lingkungan Kawasan Perdesaan di Cibogo ; Bogor ; 10 dan 11 Mei 2001. Postgraduate, Bogor Agricultural University.

[4] Suparmoko. 2012. Ekonomi Suberdaya Alam dan Lingkungan (Suatu Pendekatan Teoritis) $4^{\text {th }}$ Edition. Yogyakarta : BPFE

[5] Kusnitarini, Y. 2006. Analisis Keterkaitan Konversi Lahan Pertanian Dengan Perkembangan Wilayah Dan FaktorFaktor Yang Mempengaruhinya (Studi Kasus Kota
Tangerang, Banten) [Bachelor Thesis]. Bogor Agricultural University.

[6] Anugerah, F., K. 2005. Analisis Faktor - Faktor yang mempengaruhi Konversi Lahan Sawah ke Penggunaan Non Pertanian di Kabupaten Tangerang [Bachelor Thesis]. Bogor Agricultural University.

[7] Hidayat, I. 2015. Faktor - Faktor Yang Mempengaruhi Konversi Lahan Sawah Di Kecamatan Legok, Kabupaten Tangerang [Bachelor Thesis]. Syarif Hidayatullah State Islamic University Jakarta.

[8] Irawan, B. 2008. Meningkatkan Efektivitas Kebijakan Konversi Lahan. Forum Penelitian Agro Ekonomi 26(2): $116-131$

[9] Catur, T., B., Purwanto, J., Uchyani, R., and Ani, S., W. 2010. Dampak Alih Fungsi Lahan Pertanian Ke Sektor Non Pertanian Terhadap Ketersediaan Beras Di Kabupaten Klaten Provinsi Jawa Tengah. Caraka Tani 15(1):38-42.

[10] Lagarense, V.,I., Kapantow, G., H., M., Kumaat, R., M., and Sondk, L., W., T. 2015. Faktor-Faktor Yang Mempengaruhi Alih Fungsi Lahan Pertanian di Kabupaten Minahasa Selatan. Jurnal Fakultas Pertanian, 2015 (1): 1 12.

[11] Hidayat, A., H., Hanafie, U., and Septiana, N. 2012. Dampak Konversi Lahan Pertanian Bagi Taraf Hidup Petani di Kelurahan Landasan Ulin arat Kecamatan Liang Anggang Kota Banjarbaru. Jurnal Agribisnis Perdesaan 2(2): $95-107$ 